DOI: https://doi.org/10.31933/dijms.v2i3

Received: 10 November 2020, Revised: 25 December 2020, Publish: 22 January 2021

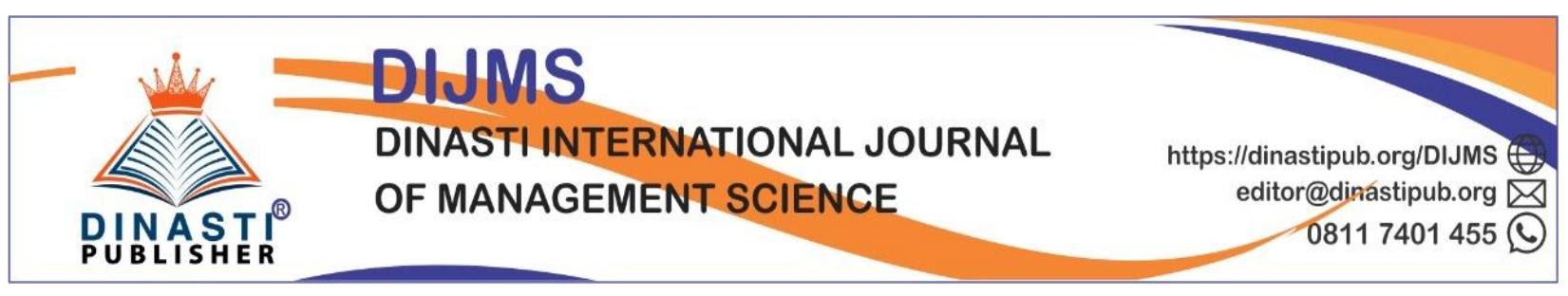

\title{
NATION AND PERSONAL CHARACTER BUILDING BASED ON PANCASILA IDEOLOGY AND HEROIC LEADERSHIP APPROACH
}

\author{
Antonius Dieben Robinson Manurung', Tika Bisono ${ }^{2}$ \\ ${ }^{1)}$ Universitas Mercu Buana, Jakarta, Indonesia, antonius.manurung@mercubuana.ac.id \\ ${ }^{2)}$ Universitas Mercu Buana, Jakarta, Indonesia
}

\section{Corresponding Author: First Author}

\begin{abstract}
The first president of the Republic of Indonesia, Sukarno, reminded the importance of the nation's strength of character which was built on the basis of a deep appreciation of the nation's view of life. Character is not only determine the existence and progress of individuals, but also the existence and progress of a group of individuals like a nation. Like an individual, in essence each nation has its own character that grows from shared experience. Referring to Sukarno's important ideas about character building, to provide lifecontents and life-direction, the soul of this nation needs to be built intentionally to reestablish Indonesian values, through awareness, empowerment, and civilization of Pancasila values and morality. Based on the problem of the target subject, efforts are needed to develop an adaptive coaching program approach model in accordance with the objectives of the target subject. The model is used as an adaptive approach in the "Nation and Personal Character Building based on the Pancasila Ideology and Heroic Leadership Approach" as an effort to change the character and mindset of prisoners. The results of this dedication are expected to contribute to the Salemba class IIA correctional institutions (prisons), the prisoners, and all parties who are concerned in guiding prisoners.
\end{abstract}

Keywords: nation and personal character building, pancasila, heroic leadership, correctional institutions, prisoners.

\section{INTRODUCTION}

Based on the Decision Letter of the Minister of Law and Human Rights No. M.02PR.07.03 2007 dated February 23, 2007 the Salemba Class IIA Penitentiary Technical Implementation Unit was formed with the main task of carrying out prison inmates. Furthermore, the main tasks are manifested through the following functions: (1) conducting training for inmates; (2) providing guidance, preparing facilities and managing work results; (3) conducting social/spiritual guidance for inmates; (4) conduct security maintenance and discipline of Penal Institutions; and (5) doing administrative and household matters.

Prisoners correctional programs should provide positive support for prisoners, especially in terms of changes in character and mindset. Character, habits, culture, and 
actions basically start from the mindset of the individual. Mindset has such a powerful influence on a person's life that affects the outlook, attitudes, and steps taken in addressing all forms of life dynamics. The wrong mindset will lead individuals in the wrong direction, and vice versa. The right mindset is really needed by every individual in supporting the existence of his life in the future.

Therefore, character education, especially related personally and as part of the nation is urgent and important, especially for prisoners. Manifestation of character education can be seen from how much the will and desire of individual prisoners to change old and bad habits into new and good habits. One form of treatment that can be given to prisoners is a high awareness of the importance of life values, morals and ethics. Life values are needed as a preparation for self-preparation after returning to the community.

The values of life provided are a program of building the character of the self and the nation that is integrated with the whole process of fostering prisoners, starting from the prison environment, activity programs, and other personal development activities. Value education is essentially continuous and lasts for life. Values education for prisoners is built in a nonformal and/or informal way through the transfer of knowledge, experience, skills, and attitudes within the prison system.

The main value education that needs to be socialized and internalized by prisoners is the education of the character of the nation and the nation that breathes on Pancasila, starting from a strong awareness of the importance of religious culture, developing human values, the spirit of nationalism, deliberation, and applying the principles of justice in life.

In addition, the values contained in Pancasila also contribute greatly to changes in attitudes and behavior of a person, from radicalist-fundamentalist, individualistic and selfwinning attitudes, to powerlessness in spirituality towards attitude of Pancasilaism.

Pancasila as an ideology evokes ideological beliefs and as a basis for the state to build constitutional beliefs (Latif, 2017). Pancasila should be developed as an applied ideology because in essence Pancasila is an open ideology that is always able to interact dynamically (Manurung, 2017). Furthermore, Manurung 2017 added that the values of Pancasila must not change, but their implementation must be adjusted to the needs and real challenges that will always be faced at any time. Pancasila as the basis of the Indonesian state must become a reference in running the life of the nation and state, various challenges and internal threats carrying out the Pancasila ideology is also unable to replace the Pancasila as the ideology of the Indonesian people.

Penitentiary as a technical implementation unit should be able to develop the main tasks and institutional functions based on the virtue values of the Pancasila itself. Thus, correctional institutions are able to instill the values of Pancasila in individual prisoners so that they are built up with their own character with strong nationalism and patriotism. Strong nationalism and patriotism are inspirations for prisoners so that they have a strong desire not to do wrong and even wrong attitudes and behavior in the future.

The transfer of knowledge, experience, and skills for inmates must be full of values. It is increasingly recognized that the transfer of knowledge, experience, and skills without prioritizing the transfer of values will only grow inmates who are cognitively and skillfully skilled, but have fundamental weaknesses in affection, understanding and applying life 
values. The basic understanding of affection is manifested in the awareness of the importance of respect for fellow prisoners, respect for officers and prison management, a strong desire to love the family, a desire to serve the community, a disciplined attitude, a spirit of lifelong learning, identity, future vision front, achievement motivation, cooperation, light hands, selfintegrity, and a number of other positive characters needed in life.

In the value-based coaching program which is certainly a mission of correctional institutions, a variety of character education approaches are needed, both of which are integrated with coaching within institutions and outside institutions, which are specific in nature and are provided with certain methods for prisoners. Specific approaches with certain methods referred to take place in the form of coaching by using the experential learning approach (learning while experiencing).

Guidance provided to prisoners is a stimulus, and becomes meaningful when prisoners who take part in the program commit themselves to practice it in their daily lives. This coaching is designed in such a way as to help trained prisoners have a strong reflective attitude from every action in the learning process experienced, both within the institution and outside the institution.

In this coaching, value training in character building uses the Pancasila approach as spirituality and a heroic leadership approach based on 4 (four) pillars, namely: selfawareness, ingenuity, love, and a burning passion/enthusiasm (heroism). The coaching program is part of the Mercu Buana University Psychology Faculty community service program which is focused on prisoners of Class IIA Penitentiary (Lapas) Salemba, Jakarta.

The initial observations made by the team regarding the condition of prisoners showed "concern and hope". In the concern of responding to the reality of prisoners, there is still a 'lump' in the hope that the wind of change for the better and more positive direction will be more directed to the future of prisoners in class IIA Salemba prison.

The technique used in the observation process is through a SWOT analysis. SWOT analysis is the systematic identification of several factors to formulate an organizational strategy based on thinking that can optimize strengths and opportunities, but simultaneously overcome weaknesses and threats. SWOT is a tool that is designed and used as a first step in the decision-making process and as a strategic planning in various applications, which can systematically help identify external factors $(\mathrm{O}$ and $\mathrm{T})$ and internal factors ( $\mathrm{S}$ and $\mathrm{W}$ ).

In general, a number of questions have arisen to help understand the SWOT maps of Salemba IIA class prison inmates. The questions raised include: 1) what are the factors that are the strengths and weaknesses of prisoners?; 2) what are the factors that become opportunities and threats?; and 3) what factors can be used to improve the quality of education of prisoners?

As for describing the situation analysis more schematically, a situation analysis of class IIA Salemba prison inmates will be presented in table 1 below. 
Table 1. Analysis of strengths, weaknesses, opportunities and threats in the problem-solving framework

\begin{tabular}{|c|c|c|c|c|}
\hline No & $\begin{array}{l}\text { Strengths } \\
\text { Analysis }\end{array}$ & Weaknesses Analysis & Opportunities Analysis & $\begin{array}{l}\text { Threats and Challenges } \\
\text { Analysis }\end{array}$ \\
\hline 1 & $\begin{array}{l}\checkmark \text { The potential of } \\
\text { inmates is relatively } \\
\text { large and large. }\end{array}$ & $\begin{array}{l}\checkmark \text { undergo a relatively } \\
\text { low coaching } \\
\text { process and the } \\
\text { future direction is } \\
\text { rather weak. }\end{array}$ & $\begin{array}{l}\text { Increased awareness } \\
\text { of coaching from } \\
\text { class IIA Salemba } \\
\text { prison officers. }\end{array}$ & $\begin{array}{l}\checkmark \text { The habits and character } \\
\text { carried by inmates with } \\
\text { various back-grounds } \\
\text { hinder the effort to } \\
\text { change character and } \\
\text { mindset. }\end{array}$ \\
\hline 2 & $\begin{array}{l}\checkmark \text { A strong will to seek } \\
\text { change in character } \\
\text { and mindset. }\end{array}$ & $\begin{array}{l}\checkmark \text { The potential that } \\
\text { exists in prisoners is } \\
\text { less able to be } \\
\text { developed because } \\
\text { the environment is } \\
\text { less supportive. }\end{array}$ & $\begin{array}{l}\checkmark \text { The development of } \\
\text { community awareness } \\
\text { and social service } \\
\text { institutions; in } \\
\text { prisoners, especially } \\
\text { related to changes in } \\
\text { character and } \\
\text { mindset. }\end{array}$ & $\begin{array}{l}\checkmark \text { Family and community } \\
\text { acceptance of prisoners } \\
\text { is less positive and } \\
\text { supportive. }\end{array}$ \\
\hline 3 & $\begin{array}{l}\checkmark \text { Strong will to } \\
\text { develop oneself in } \\
\text { creative endeavors } \\
\text { (entrepreneurship / } \\
\text { self-employed). }\end{array}$ & $\begin{array}{l}\text { The development of } \\
\text { hedonism, } \\
\text { pragmatism and } \\
\text { individualistic } \\
\text { attitudes among } \\
\text { prisoners in the } \\
\text { Jakarta area. }\end{array}$ & $\begin{array}{l}\text { Concern for the } \\
\text { government in the } \\
\text { prisoner training } \\
\text { program in the } \\
\text { Salemba IIA prison is } \\
\text { increasing so that it } \\
\text { provides motivation } \\
\text { and positive support } \\
\text { for the institutions and } \\
\text { assisted Prisoners. }\end{array}$ & $\begin{array}{l}\checkmark \text { Family demands on } \\
\text { prisoners who tend to be } \\
\text { excessive and unable to } \\
\text { understand the } \\
\text { psychological } \\
\text { conditions of prisoners } \\
\text { are demotivating for } \\
\text { prisoners. }\end{array}$ \\
\hline 4 & $\begin{array}{l}\checkmark \text { Willingness and a } \\
\text { strong will and } \\
\text { efforts of prisoners } \\
\text { to prevent and } \\
\text { overcome early } \\
\text { external influence } \\
\text { that can have a } \\
\text { negative impact on } \\
\text { the psychological } \\
\text { development of } \\
\text { prisoners. }\end{array}$ & $\begin{array}{l}\checkmark \text { Psychological } \\
\text { factors that tend to } \\
\text { be immature may } \\
\text { have a negative } \\
\text { impact on the } \\
\text { change in character } \\
\text { and mindset of } \\
\text { inmates. }\end{array}$ & $\begin{array}{l}\checkmark \text { Changing the } \\
\text { orientation of services } \\
\text { from prisons to } \\
\text { correctional } \\
\text { institutions changed } \\
\text { the motivation and } \\
\text { mindset of service } \\
\text { officers in assisting } \\
\text { and guiding prisoners. }\end{array}$ & $\begin{array}{l}\checkmark \text { Community demands on } \\
\text { prisoners who tend to be } \\
\text { excessive and unable to } \\
\text { understand the } \\
\text { psychological } \\
\text { conditions of prisoners. }\end{array}$ \\
\hline
\end{tabular}

Source: Observation Results and Preliminary Study of the Proposing Team (November, 2019)

Based on the results of preliminary observations and discussions, as for the main problem formulation in this program is "how to develop an adaptive motivational seminar approach to help improve knowledge, attitudes and skills and build character based on Pancasila for prisoners of Class IIA Salemba?".

Based on the problem of the target subject, efforts are needed to develop an adaptive coaching program approach model in accordance with the objectives of the target subject. The model is used as an adaptive approach in the "Nation and Personal Character Building based on the Pancasila Ideology and Heroic Leadership Approach" as an effort to change the character and mindset of prisoners. Before applying the Pancasila ideology approach and heroic leadership model, the proposer has conducted 2 (two) researches and training on 
"Nation and Personal Character Building based on Pancasila Ideology and Heroic Leadership Approach" totaling 36 batches.

Research I was conducted in August - December 2011 with research subjects from various private universities in the Kopertis III Jakarta region (published in the proceedings book 2, October 2012, published by the Ubaya Faculty of Psychology-ISBN 978-602-189000-4). Meanwhile, research II was conducted in January-April 2013. The results showed that the application of the heroic leadership model approach could effectively improve the personal and national character (nation and personal character building).

The objectives of the training program as follows: 1) help participants understand the importance of value education (Pancasila ideology) and the "heroic leadership approach" as a more adaptive and effective approach to the development of personal and national character building; 2) help participants apply the Pancasila ideology approach and "heroic leadershi" in an effort to change their character and mindset while in the Salemba class IIA correctional facility (prison); and 3) assist the management of correctional institutions (prisons) class IIA Salemba, Jakarta to be more concerned and pay special attention to prisoners in understanding, experiencing, and applying the Pancasila ideology of the "heroic leadership" approach in building personal and national character.

The results of this dedication are expected to contribute to the Salemba class IIA correctional facility (prison), the prisoners, and all parties who are concerned in guiding prisoners. Specifically the use of this service can be conveyed as follows: 1) strengthening the role of character-based training through the Pancasila ideology approach and heroic leadership for prisoners; 2) empowering the prisoners' potentials in character-based education, so that personal and nation character building is subsequently seen from the change in character and mindset; and 3) minimize and even overcome the problems surrounding prisoners, including weakened life motivation, lack of awareness of the importance of coaching, changes in character and slow mindset, and other attitudes and behaviors that are less supportive.

\section{LITERATURE REVIEW}

The implementation of the Pancasila grounding strategy in an effort to prevent and ward off radicalism among students must begin with a correct comprehension of Pancasila itself. Pancasila as an ideology awakens ideological beliefs and serves as the basis for the state to build constitutional beliefs (Latif, 2017). Pancasila should be developed as an applied ideology because in essence Pancasila is an open ideology that is always able to interact dynamically (Manurung, 2019). Furthermore, Manurung (2019) added that the values of Pancasila should not change, but its implementation must be adjusted to the real needs and challenges that will always be faced at any time. Pancasila as the basis of the Indonesian state must be a reference in carrying out the life of the nation and state, because of the various challenges and threats in carrying out the Pancasila ideology are also unable to replace Pancasila as the ideology of the Indonesian nation.

Of course, in an effort to implement the Pancasila grounding strategy, a model framework of stages and problems is needed. According to Manurung (2019), as for steps in implementing solutions to overcome partnership problems are as follows: 


\section{1) Developing Adaptive Strategies in the Internalization / Civilizing of Pancasila as the basis of the state, ideology and national spirituality}

Pancasila as the basis of the state, ideology, and national spirituality can be understood through its five principles as a whole and integrated from one principle to another.

The first precept: 'Belief in the one and only God' should result in development of ethical, moral, spiritual values and manifest in respect for others of different religions / beliefs. The embodiment of the first precept should be understood as a cultural Godhead, not an institutional religion. Cultural divinity is a spiritual journey that is contextual to the conditions of the nation and homeland.

The second precept: 'A just and civilized humanity' gives hope for the growth of the nation's civilization, the development of science and technology which is full of human values, which are manifested in an attitude of loving each other. The embodiment of the concept of humanity is reflected in the relationships between humans who view each other as brothers and sisters who deserve respect. In essence, the task of life is the process of fully humanizing humans.

The third precept : 'Unity of Indonesia' is the unifier of difference and diversity, which is manifested in an attitude of love for the homeland, placing the interests of the state and nation above personal and group interests. The value of unity in the concept of nationalism is no longer reduced to loyalty to power, but is returned to a national value that is rooted in the reality of community life. First of all, the efforts at unity should not be understood as an order of power, but rather a shared awareness obtained by the experiences of human life in relation to their environment. The unity of Indonesia also includes a deep understanding and appreciation of Mother Earth and Mother's Womb which shows human and divine intimacy towards the universe (the archipelago) as respect and embodiment of the values of love for life.

The forth precept: 'Democracy led by Inner Wisdom in consultation/representation' contains the values of people's sovereignty and is obedient to the legitimate decisions of the people. The populist concept must be understood more broadly. Democratic values are not only seen in the understanding of political power democracy which is reflected in political representation in the MPR, DPR, DPD, DPRD and is laden with the interests of the rulers, but puts forward or prioritizes people's nature because in essence the people are divine masters of piece and masters of their lives. The tradition of deliberation and consensus as a form of local wisdom has basically become an attitude of living together in a community that is not formed on a formal and verbal level, but is united in harmony and kinship.

The fifth precepts: 'Social justice for the entire people of Indonesia' which are able to realize social welfare without human exploitation of humans, are manifested in an attitude of equal happiness. The concept of justice first touches on the principle of "equal feeling - equal happiness" which is manifested in togetherness, brotherhood, solidarity, and partiality for the poor and oppressed people (preferential option for the poor). The principle of social justice opposes all forms and manifestations of individualism / prioritizing personal interests, neocapitalism liberalism and neocolonialism-imperialism which have damaged the joints of mutual cooperation that have become the characteristic and personality of the nation. 
The common thread of the five Pancasila principles is reviving ideological beliefs and constitutional beliefs for the people of the nation and state of Indonesia. Ideological beliefs and constitutional beliefs help all elements of the nation to fight for Pancasila as an applied ideology and an applied ideology (working ideology) in solving the complexity of the nation's problems. Sukarno in his speech dated September 30, 1960 at the 15th General Assembly of the United Nations (UN) delivered a monumental speech entitled "To Build The World Anew" and is said to be one of the best speeches ever delivered at the highest forum of the United Nations and deserves to be proposed as a world memory heritage (memory of world). One part of Sukarno's speech was: "we want a new world full of peace and prosperity, a new world without imperialism and colonialism and without 'exploitation de l'homme par l'homme' and 'exploitation de nation par nation'."

Furthermore, Sukarno (1964) reiterated in his speech known as "Vivere PericolosoTAVIP Year" on August 17, 1964, that "our revolution is not just expelling the Dutch Government from Indonesia; our revolution goes further than that; the Indonesian revolution towards three well-known frameworks: 1). towards Socialism !, 2) towards the New World without 'exploitation de l'homme par l'homme' and 3) without 'exploitation de nation par nation'. The enemy of the Indonesian revolution at this time is not only capitalismcolonialism-imperialism that has taken place in the past. Today we face the enemy of revolution in different forms, including; roots and growth of various radicalism movements transnational fundamentalism, colonialism neo liberalism, neo colonialism-imperialism which penetrate into the joints of politics, economy and culture which in the end can disrupt the existence of a nation.

By understanding, living and applying the Pancasila approach as a basis of state, ideology, and national spirituality, the nation will build personal and national character for students. Thus it is hoped that students will be able to prevent and ward off all forms and manifestations of radicalism infiltration, both in thought patterns, taste patterns, and attitude patterns. In addition, students are expected to have positive attitudes and behaviors in achieving achievement (achievement motivation).

\section{2) Heroic Leadership Approach Model (Heroic Leadership)}

Apart from using Pancasila as a soul of personal and national character development, it is also necessary to apply a heroic leadership approach. Heroic leadership is essentially a contribution to leadership wisdom and a progressive-revolutionary approach that sees leadership through a prism that is very different and biased through that prism. Heroic leadership (Lowney, 2005) appears in different light, including:

a) We are all leaders, and we lead all the time, in good or bad ways.

b) Leadership comes from within: it has to do not only with what I do but also to who I am.

c) Leadership is not an act, but a way of life.

d) Leadership is a continuous process of self-development.

What is the secret of heroic leadership? How does each individual become a leader? Manurung (2011) emphasizes the four principles of heroic leadership Lowney (2005) guides each person in: 
a) Self-Awareness: "Organizing Your Own Life"

Leaders thrive by understanding themselves well and what they value, by becoming aware of hidden points of weakness or weaknesses that can lead to deviations and by maintaining a habit of self-reflection and non-stop learning throughout life.

b) Ingenuity: "The Whole World Will Be Our Home"

Leaders make themselves and others comfortable in a changing world, by exploring new ideas, ideas, approaches and cultures, rather than defensively withdrawing from what is quietly in the way of life's next turn. Bonded to inexorable principles and values, maintains a "detachment - freedom" that allows individuals to adapt with confidence.

c) Love: "with a love greater than fear"

Leaders face the world with a healthy, confident understanding of themselves that is gifted with ability, talent, dignity and potential to lead. These same qualities are also found in others and in a burning spirit are committed to respecting and unleashing the potential that exists in oneself and in others. The leader creates an environment that is bound and motivated by loyalty, affection and mutual support.

d) Heroism: "Generating Great Desire"

Leaders envision an inspiring future and strive to make it happen rather than passively watching the future unfold around them. Heroes take gold out of opportunities rather than waiting for golden opportunities to be presented to them. The heroic leaders with full confidence turns problems and challenges into opportunities, even able to arouse the spirits of others around them.

The heroic leadership approach model is expected to have a positive influence on the development of personal and national character and have an impact on increasing achievement motivation, which is further described in Picture 1 below.

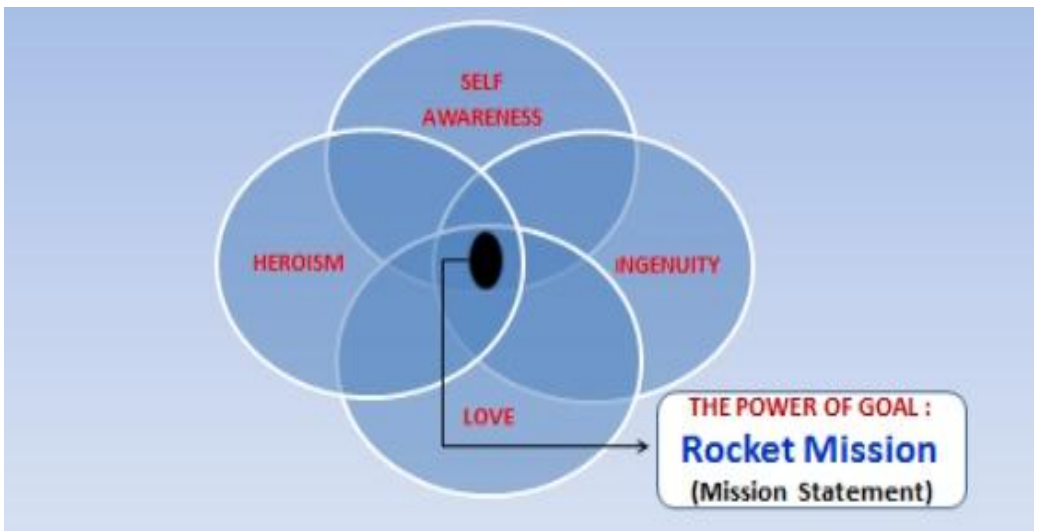

Picture 1. Model of heroic leadership approach in personal character building and the nation to increase achievement motivation (Manurung, 2015)

Picture 1 above shows the core competencies of the nation and personal character building training module. The four pillars of character building: "self-awareness, ingenuity, love and heroism" must be integrated and influence one another. Furthermore, the four 
characters are manifested in the mission statement (rocket mission) as the power of achievement. Thus, in the end, the main character possessed by the leader will radiate strongly both inside and outside. The four main pillars are summarized in an adaptive manner to the participants so that the participants can understand that these pillars are needed for achievement motivation, both in study, career and life. In the end, the four pillars above will have a positive effect on personal character.

Gough (2020) reveals that character is destiny by mentioning the following wise words: "... sow a thought, reap an act; sow an act, reap a habit; sow a habit, rap a character; sow a character, reap a destiny." So, what the destiny of each student looks like, depends on their thought. If their thought is positive, then they will also reap a positive destiny, and vice versa. Positive destiny ultimately has a positive impact on increasing achievement motivation, both on and off campus.

\section{RESEARCH METHODS}

This training program in the form of training uses experiential learning methods (learning and practicing while experiencing) with interactive communication techniques, dialogue, discussion, auto-suggestion, reflective, role play / games, and rocket missions, where participants are introduced to the concept, then directly involved and feel, experience, discuss the process and results of this training to get to know, understand, be aware of and be able to apply and increase the maximum potential for self-change in character and mindset. Evaluation is carried out to measure learning outcomes in training. Evaluation techniques use: self-introduction sheets, pre and post-test sheets, and assessment sheets (evaluations), impressions and messages.

\section{Cooperation}

This training was held in collaboration between the Faculty of Psychology Mercu Buana University, Community Service Center (P2M) Mercu Buana University with Universiti Malaysia Sabah (UMS) and The Salemba IIA Class Correctional Institution in Jakarta. The UMB helped provide instructors, handouts, pre and post-test materials, evaluations, lunch and snacks. UMS support: learning/training modules, certificate, banner, etc., While the Salemba IIA Class Class Correctional Institution in Jakarta assists the training venue accommodation and equipment.

\section{Participant}

Participants in the training of the Salemba IIA Class Correctional Institution in Jakarta are prisoners, with total 30 participants.

\section{Organizing Committee}

The organizing committee of this training program are active students of the Faculty of Psychology, Mercu Buana University, which is determined by the head of the program executive, with total of 3 (three) students, namely (1) Rini Intan Srikandi; (2) Tania Jerrly Darma. P; (3) Riesafitriani Nur Azizah.

\section{Instructor}

Instructors in this training program as follows: 
1) Dr. Antonius Dieben Robinson Manurung, M.Si. (Lecturer of the Psychology FacultyUMB and Motivation Trainer).

2) Dra.Tika Bisono,MPsi.T.,Psychologist (Lecturer of the Psychology Faculty-UMB).

\section{Time and Place}

The training activities will be held on Saturday, February, 1, 2020, from 08.30 until 12.30, at the the Salemba IIA Class Class Correctional Institution in Jakarta, J1. Percetakan Negara 88A, Rawasari, Cempaka Putih, Jakarta Pusat, DKI Jakarta 10570.

\section{FINDINGS AND DISCUSSION}

\section{Facilities and Infrastructure Description}

Generally, the places and facilities provided by Salemba Class IIA Prison, Jakarta for Nation and Personal Character Building activities are relatively comfortable, both in terms of size, air conditioning, and cleanliness. The number and conditions of chairs and tables needed for participants are sufficient and adequate. LCD projectors, laptops, sound systems, and other presentation equipment can also function properly without problems. The class or meeting place used is the Griya Belajar 'Ki Hajar Dewantara' room, it seems that learning needs to get more attention from prison management, so that it can function more effectively in the learning process, especially for prison inmates in the future. In this training, all participants and companion participants get snacks and soft drinks.

\section{Participants}

Overall, when entering the room, almost all participants seemed enthusiastic and prepared to participate in the activities to be carried out. Participants were also orderly and showed polite and courteous attitude towards instructors and assistants. The participants were also seen participating in arranging small changes regarding the layout of the room. During the training process, the participants seemed active and asked a number of questions to the instructor and the team. This shows the positive attitude of the participants, among them, a cheerful, lively, active, serious attitude from the beginning to the completion of the activity.

The training team prepares materials (handouts)and stationery for all participants, so that participants can learn the material delivered during learning in class and of course it is hoped that the material shared can be learned to be better understood by the participants. The observations made by the team showed that the participants generally could grasp the meaning and objectives of the activity, although some participants seemed to choose to remain silent, as if they were less enthusiastic, even though the silence itself did not necessarily indicate that someone was less enthusiastic. This can be seen from the contents of the program evaluation questionnaire where most said that they could understand what was conveyed from all of these training sessions. They also felt that the atmosphere of the program was fun and interesting, although there are still some opinions that feel they are not given the opportunity for group discussion because of the limited time. However, they gave positive written comments that they were inspired through this training program and were optimistic that they could become better personal than before. 


\section{Instructor / Assistance Team}

The instructor and assistant team looked harmonious and support each other in the whole process of the activity. This is known from the good cooperation between the instructor team and the prisoner, even in a short time and no prior collaboration experience. In the introductory session, the prisoner escorts provide brief direction and guidance regarding the training that will take place. The facilitators also gave observations on the whole process of the activity, so that it was hoped to provide valuable input and suggestions for the instructor team and participants in further training in the future. The instructor team seemed to be able to arouse the enthusiasm of the participants, so that it didn't feel that the time was running very fast and felt less by the participants.

\section{Activity Process}

Basically, activity process takes place in accordance with the agreed plan between the instructor team and the assistant team, before the training event takes place. The opening ceremony began with singing the 'Indonesia Raya' Song, which gave a distinct impression and aroused the enthusiasm of the participants. Furthermore, the facilitator was given the opportunity to convey direction and guidance to the participants so that they could participate in all training sessions properly and in an orderly manner.

In delivering the initial material, the instructor invites the participants (prison inmates) can be more aware of why they are present in this training. Of course, not only because of the Class II A Lapas collaboration program with the PPM Faculty of Psychology UMB, but because of concerns over the existence of prisoners who were deemed necessary to gain new inspiration and understanding related to character building and management calling of Class II A Lapas and the PPM Team of the Faculty of Psychology UMB contribute and at least be present in every person of the prisoner. Next, the instructor invited the participants to understand the importance of the training with the theme "Nation and Personal Character Building" based on the Pancasila Ideology and the Heroic Leadership Approach. Through a persuasive communication approach.

Throughout the process, dynamics with games that impress the "enjoy" or "relax" side are seen alongside the "serious" side of some other programs. It seems that participants can release fatigue and daily routines while in prison. It turns out, from the team's observation, it is known that the peserta has relatively strong nationalism and patriotism and high expectations through this training the participants can increasingly realize the importance of the process of earthing the Pancasila for all citizens of the nation, including prisoners everywhere. As citizens of the nation, everyone must be able to lead and have a strong attitude of heroism so as not to be easily influenced by various trials and temptations, which of course contradicts the noble values of Pancasila as national identity.

Before the activity ended, the instructor invited the participants together and deeply to sing the song 'Peace with You', created by Chrisye, which evoked the confidence and awareness of each participant that life's journey was essentially about making peace with oneself to be able to make peace with others, make peace with nature, and especially make peace with the Divine. This song is certainly expected to be able to break down the barrier of individual (personal) success of the participants with all the complexity of the problems they are experiencing, so that they are expected to have a strong self-belief in success. The session 
ended with singing the song 'Bagimu Negeri', farewell speech, and a photo with the Salemba Class II Lapas Leaders, Participants, Team instructors, and Participant Assistance.

\section{Instructor and Assistance Team Evaluation}

Based on the results of the evaluation conducted by the instructor and advisory team, there are a number of inputs and suggestions for improvement and improvement of training programs for prisoners in the future.

a) More time is needed for training delivery.

b) Continuity of the program is desirable, so that service coverage and assistance is broader and has a more positive impact.

c) Training facilities are expected to be further improved so as to create a more conducive and impactful atmosphere.

d) Development and enrichment of material with the same theme are needed in future training.

e) Collaboration between Salemba Class IIA Prison Management and the UMB Faculty of Psychology needs to be further improved in psychological assistance programs, both for prisoners and prison staff / employees.

\section{Participants Pre-Post Test, Program Evaluation, and Instructors Evaluation Result}

Evaluation results of participants related to pre-post tests are described in the Table 4.

Table 4. Pre and post-test result

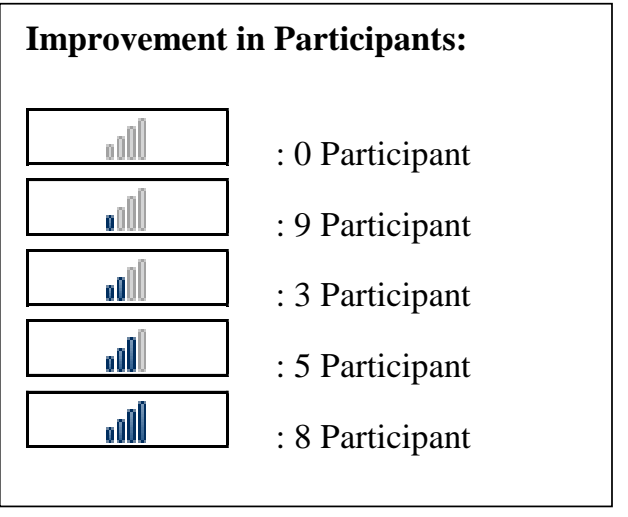

$\begin{aligned} & \text { Value Remarks, } \\ & \text { Pre-test: }\end{aligned}$
$\begin{array}{ll}\leq 30 & \text { : Very bad } \\ 31-40 & \text { : Bad } \\ 41-50 & \text { : Less } \\ 51-60 & \text { : Enough } \\ 61-70 & \text { : Pretty good } \\ 71-80 & \text { : Good } \\ 81-90 & \text { : Very good } \\ 91-100 & \text { : Excellent }\end{array}$

Value Remarks, Post-test:

$\leq 40 \quad:$ Very bad

41-50 : Bad

$51-60 \quad:$ Less

61-70 : Enough

71-80 : Pretty good

81-90: : Good

$91-95$ : Very good

96-100 : Excellent

Based on the data and description above it can be concluded that Participants received an average pre-test score of $44.8 \%$ (classified in the "Less" category) and an average post-test score of $87 \%$ (classified in the "Good" category). Then it can be seen an increase from the participants either individually or as a whole.

Then, the results of the program evaluation can be summarized for question item stated "I can understand what I learned throughout this training session", 76\% of participants found "Strongly Disagree" 0\%, "Disagree" 1\%, "Agree" 59\%, and "Very Agree" 40\%. So, this program of activities, has a $99 \%$ positive impact, and is included in the category "Excellent".

Then, evaluation of instructors result can be summarized as follow, in the Instructor Subsection the number of statements "Strongly Disagree" 0\%, "Disagree" 1\%, "Agree" 61\% and "Strongly Agree" 37\%. Then the Evaluation from the Instructor is classified as $98 \%$ or 
"Excellent". Sub-section material amount of statement "strongly disagree" 0\%, "Disagree" 1\%, "Agree" 71\% and "Strongly Agree" 28\%. Then the Evaluation from the Instructor is 99\% or "Excellent". The last subsection, namely atmosphere, both situations and conditions, the number of statements "Strongly Disagree" 0\%, "Disagree" 0\%, "Agree" 49\% and "Strongly Agree" 51\%. Then the Evaluation from the Instructor is $100 \%$ or "Excellent". From all accumulated overall then the number of statements "Strongly Disagree" 0\%, "Disagree" 1\%, "Agree" 62\% and "Strongly Agree" 37\%. Then the Evaluation from the Instructor is classified as $99 \%$ or "Excellent".

In addition to the quantitative data above, participants also wrote narratives related to the things that are most valuable and useful to the participants in this training, which are further described below:

1) Self-awareness is awakened, getting to know yourself and the nation better.

2) A togetherness sense and deeper brotherhood was developed among the participant.

3) Adding national knowledge, experience and insight, specifically it is related to Pancasila as a provision when it is free / out of prison.

4) The spirit of life is awakened for a better change going forward.

5) Understand the importance of character building for inmates as a basis to make changes themselves, especially in overcoming life's trials.

6) Realizing that the participant turned out his life was still useful.

7) Motivate and strengthen character to become a better person, more confident, positive thinking, optimistic, and not giving up easily.

\section{CONCLUSION AND RECOMMENDATION Conclusion}

Independence has an effect on the change in prison orientation. The government is trying to turn it into a prisoner's education before returning to the community. Then in 1962 the concept of Penitentiary emerged in accordance with its function, preparing prisoners to return to the community with better character and mindset so as to create new habits that impact on the physical and psychological well-being of individuals. Based on the results of the analysis of this activity, conclusions can be drawn as follows:

1) Pancasila as the state foundation, ideology, and national spirituality must be able to become the main foundation for character building for prisoners in the Penitentiary in raising awareness of the importance of religious values, beliefs and culture, developing human values, the spirit of nationalism, deliberation, and applying the principle of justice in life.

2) Values education for inmates/prisoners needs to be built informally and / or informally, which is important to motivate and form a high awareness for prisoners in preparing themselves to return to the community later. This will also help the process of adaptation in the framework of approaching a more useful life, actively playing a role in development, and being able to live reasonably as a good and responsible citizen.

3) The concept of heroic leadership (Lowney, 2005) can be used as a reference in setting goals of programs developed by the Penitentiary in order to raise self-awareness to organize a better personal life, to realize that making the world better is a shared responsibility, giving rise to love to others, and motivate in realizing better life goals. 
4) Training of personal and national character building based on Pancasila and a heroic leadership approach for prisoners are seen as a necessity, important and urgent to be made a program in correctional institutions.

5) Psychological approach is the adaptive methods that needs to be developed thoroughly, holistically, and continuously in an effort to help recovery and strengthening mental, emotional, and spiritual for prisoners.

\section{Recommendation}

Some recommendations that can be submitted as follows:

1) The need to hold regular programs in the form of seminars, Focus Group Discussions (FGD), and training related to the deepening of the Pancasila points as a foundation for character buildings.

2) The importance to arrange a program of activities that involve the community around the Penitentiary in order to provide motivation for prisoners to facilitate the process of adaptation in social life.

3) The need to hold activities that can foster self-confidence and can become leaders in the community.

\section{REFERENCE}

A Character Education Partnership. (2003). Character education quality standards. Washington : Character Education Partnership

Ancok, Dj. (2002). Outbound management training. Yogyakarta : UII Press

David, R.F. (2015). Strategic Management: A Competitive Advantage Approach, Concepts.15th Edition.Prentice Hall

Gough, W.G. (1998). Character is destiny: the value of personal ethics in everyday life, USA : Forum, Prima Publishing.

Latif, Y (2017), Mata air keteladanan Pancasila dalam perbuatan. Jakarta : Mizan.

Lowney, C. (2005). Heroic leadership, Chicago, Illinois : Loyola Press. (2009). Heroic living (terjemahan). Jakarta : Gramedia Pustaka Utama

Manurung, A.D.R. (2011). Efektivitas model pendekatan kepemimpinan heroik dalam pelatihan "personal character building bagi para mahasiswa di jakarta.proceeding, Lustrum Ubaya, Surabaya

(2013). Efektivitas model pendekatan kepemimpinan heroik dalam pelatihan "personal character building bagi para siswa di jakarta. Hasil Penelitian (belum diterbitkan), Jakarta : UMB

(2019). Raison d'etre: pancasila sebagai ideology dan dasar negara. Jakarta: Gerakan Pembumian Pancasila

Mulyana, E.H. (2012). Manajemen pendidikan karakter. Jakarta : Bumi Aksara

Riyanto, A., Ohiotimur, J., Mulyatno, C.B., \& Madung, O.G., (2015) Kearifan lokal Pancasila, butir-butir filsafat Keindonesiaan, Editor, Yogyakarta : Kanisius

Sastraprateja, M. (2013). Lima Gagasan yang dapat mengubah Indonesia. Jakarta: Pusat Kajian Filsafat dan Pancasila 
Soekarno (2010). Indonesia menggugat. Jakarta : Fraksi Partai Demokrasi Indonesia Perjuangan DPR-RI (1964) Di bawah bendera revolusi. Jakarta : Panitya Penerbit

Taylor, E.S., Peplau, A.L. \& Sears, O.D. (2009). Social psychology. Los Angeles: Prentice. 